Far Eastern Entomologist

\begin{tabular}{lll}
\hline Number 439: 24-28 & ISSN 1026-051X (print edition) & October 2021 \\
\hline
\end{tabular}

https://doi.org/10.25221/fee.439.3

http://zoobank.org/References/6E598E1D-7BFD-4E4E-96D4-C10CC5185250

\title{
FIRST RECORD OF ANAX NIGROFASCIATUS OGUMA, 1915 (ODONATA: AESHNIDAE) FROM RUSSIA
}

\section{E. I. Malikova ${ }^{1)}$, Yu. A. Chistyakov ${ }^{2)}$}

1) Blagoveshchensk State Pedagogical University, Blagoveshchensk, 675000, Russia. E-mail:e_malikova@inbox.ru

2) Federal Scientific Center of the East Asia Terrestrial Biodiversity, Far East Branch of the Russian Academy of Sciences, Vladivostok, 690022, Russia.E-mail: chistyuri@mail.ru

Summary. Dragonfly Anax nigrofasciatus Oguma, 1915 (Odonata: Aeshnidae) was collected on a small pond in the vicinity of Vityaz settelment, Gamov Peninsula, Primorsky Krai in 2021. It is the first record of this East Asian species from Russia. A. nigrofasciatus clearly differs from A. parthenope julius Brauer, 1865, more common in the south of the Russian Far East, by body coloration and by details of morphology. East.

Key words: Odonata, dragonflies, Anax, fauna, new record, Primorsky Krai, Russian Far

Е. И. Маликова, Ю. А. Чистяков. Первая находка Anax nigrofasciatus Oguma, 1915 (Odonata: Aeshnidae) в России // Дальневосточный энтомолог. 2021. N 439. С. 24-28.

Резюме. Anax nigrofasciatus Oguma, 1915 (Odonata: Aeshnidae) был собран на небольшом пруду в окрестностях пос. Витязь, п-ов Гамова, Приморский край в 2021 г. Ранее этот восточноазиатский вид для территории России не указывался. От более обычного на юге Дальнего Востока России A. parthenope julius Brauer, 1865 этот вид легко отличается по окраске и деталям морфологии.

\section{INTRODUCTION}

So far, five taxa from the genus Anax have been reported for Russia, namely A. ephippiger (Burmeister, 1839), A. imperator Leach, 1815, A. junius (Drury, 1773), A. parthenope parthenope (Selys, 1839), A. parthenope julius Brauer, 1865 (Malikova \& Kosterin, 2019). The first two are distributed in the European part of the country, A. parthenope parthenope is found also in Siberia east to Omsk and the Tyva Republic (Kosterin, 2007; Kosterin \& Zaika, 2011). A. junius is a stray species reported twice from Kamchatka in XIX - early XX centuries (Hagen, 1856; Bartenev, 1912). The only registered representative of this genus in the Russian Far East was A. parthenope julius native to Korean Peninsula, Japan, China, and Vietnam (Malikova, 2010). A species of Anax that is new for Russian fauna was collected in the south of Primorsky Krai, Russian Far East. The studied specimens are deposited in the Federal Scientific Center of East Asia Terrestrial Biodiversity, Vladivostok, Russia [FCBV] (formerly the Institute of Biology and Soil Science). 


\section{NEW RECORD}

Family Aeshnidae Rambur, 1842

Anax nigrofasciatus Oguma, 1915

Fig. 1

Anax nigrofasciatus Oguma, 1915: 121. Type locality: Okayama; Kyoto, Totomi; Tokyo [Japan].

MATERIAL EXAMINED. Russia: Primorskii krai, Khasanskii district, Gamov Penin-

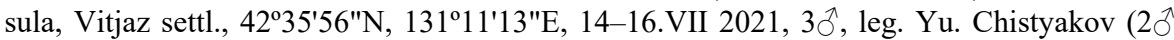
deposited in FCBV; 10 was taken alive from a spiderweb and then released).

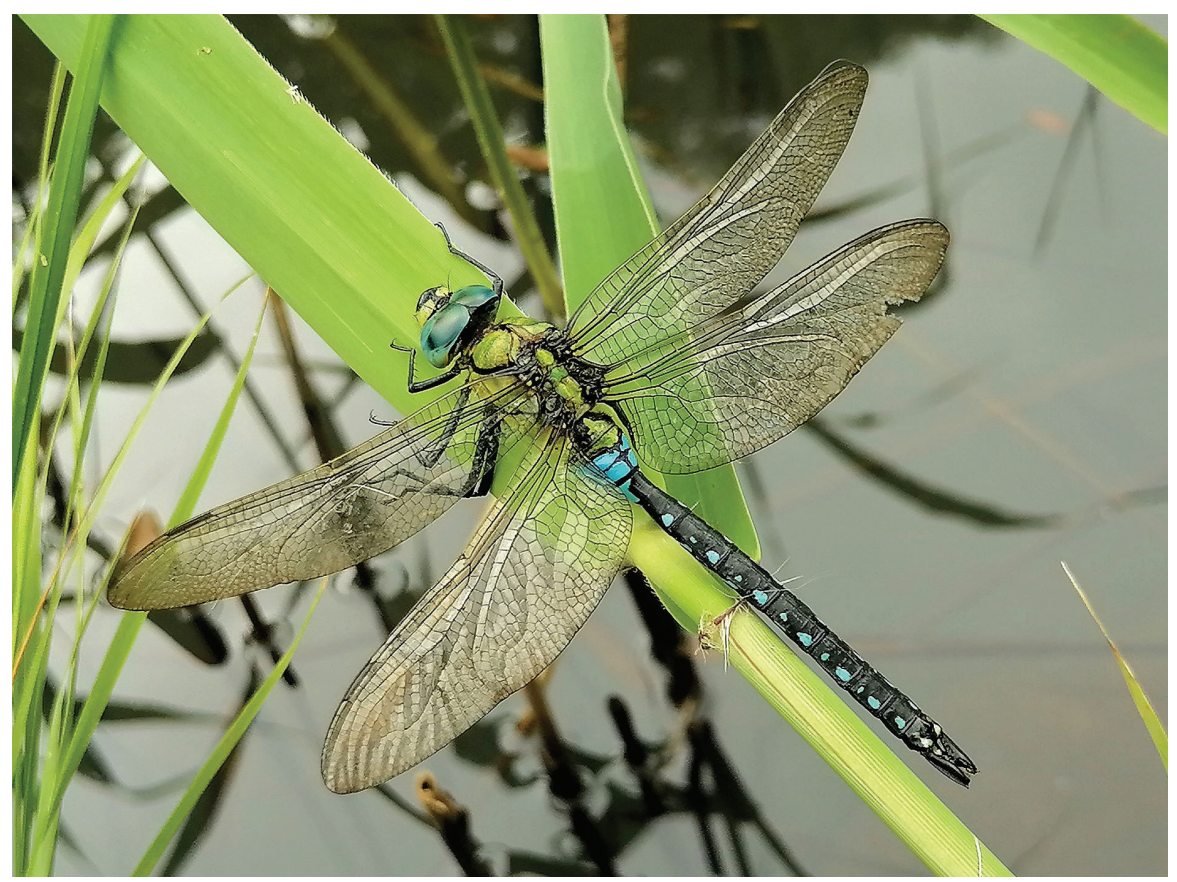

Fig. 1. Anax nigrofasciatus, resting male. (Photo by Yu.A. Chistyakov).

HABITAT. Collecting site (Fig. 2) is located about $150 \mathrm{~m}$ from the sea shore in a boggy valley with sparse spreading trees of Salix caprea, S. udensis, Alnus japonica, A. hirsuta and Fraxinus mandshurica where there are two rather small, no more than 200 square meters each, 20-year-old artificial ponds. The depth of the ponds is about 2 meters or even less; their banks are occupied by the same vegetation that used to grow in this valley: Calamagrostis langsdorffii, C. extremiorientalis, Lithrum salicaria, Poa pratensis, Carex maackii, C. rhynchophysa, Juncus decipiens, Scirpus asiaticus and others. Shallow areas of the ponds are overgrown with Calla palustris, Phragmites communis and Typha orientalis. The water surface is mostly covered by Nymphoides peltatum. 


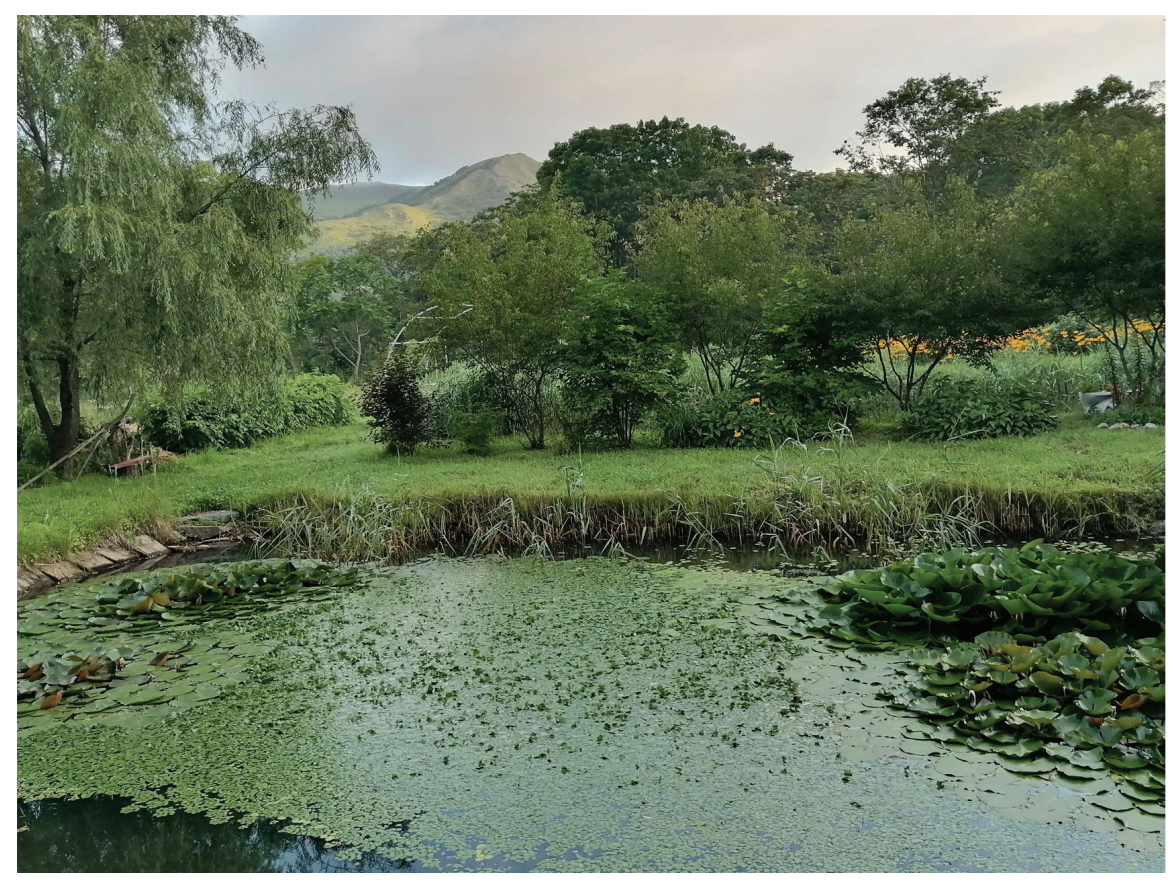

Fig. 3. Habitat of Anax nigrofasciatus in Russia (Primorsky Krai, Gamov Peninsula). (Photo by Yu.A. Chistyakov).

DISTRIBUTION. The species occurs in Japan except Hokkaido (Sugimura et al., 2001), in South Korea (Lee, 2001), North, East, South, and Central China (Hua, 2000), Hong Kong (Reels, 2019), Taiwan (Lieftinck et al., 1984; Wang, 2000), and Vietnam (Cuong \& Hoa, 2007). The record from the Philippines is considered doubtful (Wilson, 2009).

COMMENTS. A. nigrofasciatus is easily distinguished from its congeners distributed in Russia by the presence of distinct, bright black T-shaped mark on the horizontal part of frons, by black thoracic sutures on green thorax and black abdomen with 2 pairs of blue (green in females) lateral spots on tergites 3-10.

\section{CONCLUSION}

The new record of $A$. nigrofasciatus indicates its significant advance to the north in the last two decades. Lee (2001) cited no records from the north of Korean Peninsula, but Kim et al. (2020) reported it from the central part of North Korea. A number of oriental Odonata species seems advancing northward and westward recently (Malikova, 2010; Malikova \& Streltsov, 2015) and this record confirms the trend. Moreover, the trend of invasions of the East Asian-Oriental species of insects into the Russian Far East has existed at least during last century but is noticeably increased during last years (Dubatolov, 2021; Spitsyn \& Spitsyna, 2021; Ustjuzhanin et al., 2021). 


\section{ACKNOWLEDGEMENTS}

We would like to express our deep gratitude to Dr. V.Yu. Barkalov (Vladivostok, Russia) for the identification of the plants.

\section{REFERENCES}

Bartenev, A.N. 1912. Contributions to the knowledge of the Odonata from palearctic Asia in the Zoological Museum of Imp. Academy of Sciences of St. Petersburg. 1. Annuaire du Musée zoologique de l'Académie impériale des Sciences de St.- Pétersbourg, 16 [1911]: $409-448$.

Cuong, D.M. \& Hoa, D.T.T. 2007. Checklist of dragonfly from Vietnam. Vietnam National University Publisher, Hanoi. 182 pp.

Dubatolov V.V. 2021. First record of noctuid moth Callopistria aethiops Butler, 1878 (Lepidoptera: Noctuidae) from Southern Primorye as an example of the East Asian species penetrating in Russian fauna. Far Eastern Entomologist, 429: 8-11. DOI: https://doi.org/10.25221/fee.429.2

Hagen, H.A. 1856. Die Odonaten-Fauna des Russischen Reichs. Stettiner entomologische Zeitung, 17: 363-380.

Hua, L.Z. 2000. List of Chinese Insects. Zhongshan University Press, Guangzhou. 448 pp.

Kim, J.-M., Song, Y.-K., Lee, J.-H. \& Kim, S.-S. 2020. The Damselflies and Dragonflies of Korean Peninsula. 292 p.

Kosterin, O.E. \& Zaika V.V. 2011. Fauna of dragonflies and damselflies (Odonata) of Tuva Amurian zoological journal, III(3): 210-245. [In Russian with English summary]

Kosterin, O.E. 2007. The first record of Anax on the West Siberian Plain: A. p. parthenope Selys in Omsk (Anisoptera: Aeshnidae). Notulae odonatologicae, 6: 112-115.

Lee, S.M. 2001. The Dragonflies of the Korean Peninsula (Odonata). Junghaeng-Sa, Seoul, Korea. $230 \mathrm{pp}$

Lieftinck, M.A., Lien, J.C. \& Maa, T.C. 1984. Catalogue of Taiwanese Dragonflies (Insecta: Odonata). Asian Ecological Society, Taichung, Taiwan. 81 pp.

Malikova, E.I. 2010. Zoogeographically interesting dragonflies (Odonata) records from the Upper Amur region. Eurasian entomological Journal, 9: 291-294.

Malikova, E.I. \& Kosterin, O.E. 2019. Check-list of Odonata of the Russian Federation. Odonatologica, 48(1/2): 49-78.

Malikova, E.I. \& Streltsov, A.N. 2015. Artificial water bodies as a base in the dispersal of dragonflies (on the sample of the Kivdinskoe Reservoir, Amurskaya Oblast). A.I. Kurentsov's Annual Memorial Meeting, 26: 76-87. [In Russian with English summary]

Oguma, K. 1915. Japanese dragonflies of the subfamily Aeschninae. Entomological Magazine, 1(3): 120-131.

Reels, G.T. 2019. An annotated check list of Hong Kong dragonflies and assessment of their local conservation significance. Journal of the International Dragonfly Fund. Faunistic Studies in South-East Asian and Pacific Island Odonata, 30: 1-49.

Spitsyn, V.M. \& Spitsyna, E.A. 2021. First record of the hawk moths genus Psilogramma Rothschild et Jordan, 1903 (Lepidoptera: Sphingidae) for the fauna of Russia. Far Eastern Entomologist, 426: 19-21. DOI: https://doi.org/10.25221/fee.426.3

Sugimura, M., Ishida, S., Kojima, K., Ishida, K. \& Aoki, T. 2001. Dragonflies of the Japanese Archipelago in Colour. Hokkaido University Press, Japan. 641 pp.

Ustjuzhanin P.Ya., Kovtunovich V.N., Dubatolov V.V. \& Streltzov A.N. 2-21. First record of the genus Nippoptilia Matsumura (Lepidoptera: Pterophoridae) from Russia. Far Eastern Entomologist, 438: 13-15. DOI: https://doi.org/10.25221/fee.438.3 
Wang, L.-J. 2000. Dragonflies of Taiwan. Jemjem Calendar, Taipei. 349 pp.

Wilson, K.D.P. 2009. Anax nigrofasciatus. The IUCN Red List of Threatened Species 2009: e.T164783A5925749. DOI: https://dx.doi.org/10.2305/IUCN.UK.2009-2.RLTS.

T164783A5925749.en. 